\title{
Shoot Multiplication of Quinine Plant (Cinchona ledgeriana Moens) With Several Concentrations of Kinetin on In Vitro
}

\author{
Reni Mayerni $^{\#}$, Erviana Eka Pratiwi ${ }^{\# 1}$, and Warnita ${ }^{\#}$ \\ \# Department of Agroecotechnology, Faculty of Agriculture, Andalas University, Padang 25163, Indonesia \\ E-mail: ${ }^{1}$ erviana.ekapratiwi@yahoo.com
}

\begin{abstract}
An experiment to determine the effect of kinetin with several concentrations on shoot multiplication of plants quinine (Cinchona ledgeriana Moens) has been conducted from December 2013 to March 2014 at the Tissue Culture Laboratory, Faculty of Agriculture, Andalas University, Padang. The experiment used a completely randomized design with five treatments and four replicates extent that (A) 0 mg/l kinetin; (B) 0,5 mg/l kinetin; (C) $1 \mathrm{mg} / \mathrm{l} \mathrm{kinetin;} \mathrm{(D)} \mathrm{1,5} \mathrm{mg/l} \mathrm{kinetin} \mathrm{and} \mathrm{(E)} 2 \mathrm{mg} / \mathrm{l} \mathrm{kinetin.} \mathrm{Data} \mathrm{were}$ analyzed using the $\mathrm{F}$ test and mean comparisons of Duncan's test New Multiple Range Test (DNMRT) at 5\% level. The treatment of $0.5 \mathrm{mg} / \mathrm{l}$ kinetin resulted in the best time to shoot emergence of 5.92 days after planting, the highest number of shoot of 15.41 , the highest number of leaves of 61.75, the highest shoot of $3.25 \mathrm{~cm}$, and highest number of shootlet fresh weight of $0.70 \mathrm{~g}$ per plant at 12 weeks after planting.
\end{abstract}

Keywords - ledger, kinetin, shoot multiplication

\section{INTRODUCTION}

Plants produce alkaloids quinine main quinoline contained in cinchona bark in the form of quinine, kinidin, sinkonin and sinkonidin. Four types of alkaloids that have high economic value. According to Dayrit et al [2], quinine is the active ingredient of anti-malarial drugs, and drug kinidin as heart disease.

Each type of alkaloid quinine quinine has different levels. C. Ledger is that many types of quinine alkaloid contains quinine. Moens (1872) states in Groothoff [6], that quinine ledger is not only superior to quinine levels were high, but this alkaloid is very easily separated as pure sulfate compared with the skins of other types of quinine, which he said is caused by the small amount of alkaloid side .

According to Madjid [16], that Indonesia has the potential to developm-ment of quinine plantations because of the climate and soil are suitable, namely in West Java and West Sumatra. West Sumatra is the second quinine crop production after West Java.

According to Santoso [22] director of PT. Sinkona Indonesia Lestari (SIL), the ability of Indonesian quinine salt production increased again to 150 tons / year to reinforce its commodity marketing quinine in the world. The purpose of revitalizing the national quinine salt production capability, also related to the competitiveness of the quinine salt imported products. With the revitalization effort to improve is through area expansion and rejuvenation of plants. According Riyadi and Tahardi [20], quinine conventional plant propagation is usually done through cuttings, grafting and grafting. However, provision of seeds by means of cuttings have difficulty in inducing rooting, whereas through grafting techniques and the connection must have a compatibility between the stem and the top of the bottom. In addition it requires a bottom stem in large numbers to do the multiplication.

Wibowo et al [26], states that the cinchona plant propagation by grafting need how long time is 8-12 months before planting material transferred to the field. To overcome these problems, efforts can be made quinine plant propagation through tissue culture techniques with soma clonal propagation or micro propagation.

Tissue culture is one way of vegetative propagation of plants. A tissue culture plant propagation techniques by means of isolating parts of the plant such as leaves, buds, as well as the parts grow in artificial media aseptically rich in nutrients and growth regulator in a sealed container that is translucent so that the plant can reproduce themselves and the generations become complete plants. The main principle of the technique is tissue culture plant propagation using vegetative parts of the plant using artificial media were performed in a sterile place.

Growth regulator (PGR) is a determining factor in tissue culture techniques, one of which cytokines. Cytokines play a 
role in encouraging the growth of cells and tissues as well as the initiation of bud formation. Several types of cytokines used in tissue culture is BAP, kinetin, 2-ip. According to Dodds and Roberts [3] that the BAP and kinetin is a synthetic cytokinin, whereas 2 -ip including natural cytokines similar to zeatin. Arteca [1] states that the BAP is stable, relatively cheaper compared to other types of cytokines, available quickly and very effectively.

According to Hartman et al [8], the use of growth regulators from the same class at the same time in some real plants better than single use. Lestari [15] states the basic media formulation and manipulation of growth regulators can optimize the activity of cell division to multiplication of shoots. Based on the author has conducted research on "The Effect of BAP With Some Concentration Kinetin Against Plant Shoots Multiplication Quinine (Cinchona ledgeriana Moens) In In Vitro ".

This study aims to determine the provision of BAP with some proper concentration of kinetin on shoot multiplication of plants quinine (Cinchona ledgeriana Moens) in In Vitro.

\section{MATERIALS AND METHODS}

\section{A. Time and Place}

These experiments have been carried out for 4 months, from December 2013 to March 2014 at the Tissue Culture Laboratory, Department of Agriculture, Faculty of Agriculture, University of Andalas, Padang (Schedule of events can be seen in Appendix 1).

\section{B. Equipment and Materials}

The tools used in this experiment were analytical balance, autoclave, hotplate, magnetic stirer, Laminar Air Flow Cabinet (LAFC), refrigerator, oven, shaker machine / shaker, litmus paper, glass cup, erlenmeyer, volumetric flask, measuring cup, funnel, micro pipette, glass stirrer, culture rack, Bunsen, label paper, aluminum foil, plastic wrap, autoclave, gas stove, scalpel, scissors, tweezers, pipette mumps, plastic glass, rubber bands, petridish, cameras, tissues, hand sprayer, meter, calipers, spatula, and stationery.

The materials used in this experiment is plant seeds of quinine (Cinchona ledgeriana Moens) derived from the Research Center for Tea and Quinine, Gambung, West Java. Murashige and Skoog medium (MS), treatment media (MS + PGR), BAP, kinetin, fungicide, bactericide, alcohol 70\%, $20 \% \mathrm{NaOCl}$, spritus, sucrose, so Phytagel, distilled water, mild detergent.

\section{The design of Experiment}

These experiments were prepared using completely randomized design (CRD). Treatment in this experiment is a combination of BAP $3 \mathrm{mg} / 1$ with a 5 degree of concentration of kinetin, namely:

(A) BAP $3 \mathrm{mg} / 1$ kinetin $+0 \mathrm{mg} / 1$

(B) BAP $3 \mathrm{mg} / 1$ kinetin $+0.5 \mathrm{mg} / 1$

(C) BAP $3 \mathrm{mg} / 1+$ kinetin $1 \mathrm{mg} / 1$

(D) BAP $3 \mathrm{mg} / 1$ kinetin $+1.5 \mathrm{mg} / 1$

(E) BAP $3 \mathrm{mg} / 1+$ kinetin $2 \mathrm{mg} / 1$
Treatment of stage 5 was repeated 4 times, so there are 20 experimental units. In each experimental unit consisted of 3 bottles of culture, so there are 60 bottles of culture. The data were statistically analyzed by $\mathrm{F}$ test and if $\mathrm{F}$ count is greater than $5 \%$, the F table followed by Duncan's New Multiple Range Test (DNMRT) at the 5\% significance level.

\section{Implementation Research}

\section{1) Provision of Planting Material}

Quinine seeds sterilized in $20 \% \mathrm{NaOCl}$ solution for 15 minutes and rinse using distilled water. Followed by sterilization in a fungicide solution $(1 \mathrm{~g} / \mathrm{l})$ for one hour on a shaker machine with a speed of $80 \mathrm{rpm}$ and rinse using distilled water. Furthermore sterilization in bactericidal solution (1 g / 1) for one hour while shaken on a shaker machine with a speed of $80 \mathrm{rpm}$ and rinse using distilled water.

Germinated seeds into MS medium without PGR for 12 weeks until the height reaches $\pm 5 \mathrm{~cm}$. Explant source to be used for shoot multiplication, a third node with a length of \pm $10 \mathrm{~mm}$.

\section{2) Preparation of Media}

The entire MS medium stock solution pipetted in accordance with the needs, myo-inositol and sucrose were weighed according to the needs, then sufficient with distilled water, the solution was stirred and homogeny. Next add the BAP and kinetin with a predetermined concentration into each cup, measuring up to $5.8 \mathrm{pH}$ media using litmus paper, add a few drops of $0.1 \mathrm{~N} \mathrm{NaOH}$ if the $\mathrm{pH}$ is less than 5.8 and with $\mathrm{HCl} 0,1 \mathrm{~N}$ if the $\mathrm{pH}$ is more than 5.8 and add that to the media each treatment.

Then the media is inserted into the culture bottle $25 \mathrm{ml}$ per bottle and covered with aluminum foil. Each bottle is labeled in accordance with the treatment used. Then the media sterilized in an autoclave at a pressure of $15 \mathrm{psi}$ and a temperature $121^{\circ} \mathrm{C}$ for 30 minutes, then bottles arranged on shelves that culture resides in the incubation chamber for one week to determine whether or not the media contaminated. Contaminated media must be immediately removed from the incubation chamber.

\section{3) Planting}

Explants planting activities carried out in the Laminar Air Flow Cabinet (LAFC) which has been sterilized. Culture bottle that already contains media, cropping tools, spritus lights and other equipment that has been sterilized before being put into LAFC first sprayed with $70 \%$ alcohol. Planting activity initiated by soaking all of the tools that are used like tweezers, scissors, and a scalpel into a solution of $70 \%$ alcohol and then burned using a Bunsen flame.

Explants to be used for shoot multiplication sterilization efforts not anymore, because these explants derived from seeds germinated in vitro in aseptic conditions. Explant source is the third node size of $\pm 10 \mathrm{~mm}$. Then these explants grown in media treatment, in which each of the bottles containing the explants. Media culture has grown closed using duct tape and clear plastic wrap, and labeled. Furthermore, culture bottles that have been completed planted, saved to incubation space and placement of the treatment plan is based on the culture shelf. 


\section{RESULT AND DISCUSSION}

\section{A. Current Appearing Tunas (HST)}

Based on Table 1 shows that administration of BAP 3 $\mathrm{mg} / \mathrm{l}$ with the addition of kinetin $0.5 \mathrm{mg} / \mathrm{l}$ and $1 \mathrm{mg} / \mathrm{l}$ to the current optimum appear shoots in vitro quinine ledger namely 5.92 and 8.08 HST while the addition of kinetin concentrations higher $1.5 \mathrm{mg} / 1$ and $2 \mathrm{mg} / \mathrm{l}$ led to the current emphasis on appear shoots ie 12.33 and 12.84 HST and treatment without the addition of kinetin less quinine stimulates shoot growth so that the buds appear at 10.83 HST. In general, the explants are able to germinate on average on day 5 to 12 days after planting. Based on experiments Santoso et al [21], the origin node germination in vitro ledger and Succi, bud initiation occurs at day 7 while the number of explants sprout has reached more than $50 \%$ of the population explants were grown at 14 HSK (Day After Culture)

TABLE I

WHEN BUDS APPEAR ON THE PROVISION OF BAP 3 MG / L WITH SEVERAL CONCENTRATIONS OF KINETIN.

\begin{tabular}{|c|c|c|}
\hline \multirow{2}{*}{ Treatment } & \multicolumn{2}{|c|}{ Average } \\
\hline & \multicolumn{2}{|c|}{ Current It comes buds } \\
\hline BAP $3 \mathrm{mg} / \mathrm{l}+$ kinetin $0 \mathrm{mg} / 1$ & 10,83 & $\mathrm{~b}$ \\
\hline BAP $3 \mathrm{mg} / \mathrm{l}+$ kinetin $0,5 \mathrm{mg} / \mathrm{l}$ & 5,92 & $\mathrm{~d}$ \\
\hline BAP $3 \mathrm{mg} / \mathrm{l}+$ kinetin $1 \mathrm{mg} / \mathrm{l}$ & 8,08 & $\mathrm{c}$ \\
\hline BAP $3 \mathrm{mg} / \mathrm{l}+$ kinetin $1,5 \mathrm{mg} / \mathrm{l}$ & 12,33 & $\mathrm{ab}$ \\
\hline BAP $3 \mathrm{mg} / \mathrm{l}+$ kinetin $2 \mathrm{mg} / \mathrm{l}$ & 12,84 & $\mathrm{a}$ \\
\hline $\mathrm{KK}=12,53 \%$ & & \\
\hline
\end{tabular}

The figures in the column followed by the same lowercase letter are not significantly different according to DNMRT 5\%

Shoots an emerging young twigs or prospective new plants that grow from the plant. Current shoots appear characterized by a greenish bumps on the leaf blade. So the first buds appear on the explant elongation of existing buds in axillary panicles.

Gunawan [7] states in the process of formation of organs such as shoots or roots there is an interaction between exogenous growth regulating substances were added to the medium with endogenous growth regulating substances produced by plant tissues. When viewed from the provision of BAP $3 \mathrm{mg} / 1$ with the addition of a low concentration of kinetin which will speed up the emergence of shoots, it is also influenced by the presence of endogenous cytokines in explants and its contents is enough to trigger the formation of buds, so it does not require exogenous growth regulator concentrations high. With the addition of a high concentration of kinetin, will inhibit the formation of buds on the explants. According Hendaryono and Wijayani [10], the addition of high levels of auxin or cytokinin on is more inhibiting than stimulating growth.

George and Sherington [5], states BAP is a growth regulator that is widely used to stimulate bud formation with a power strong activity, and encourage cell division. Natural cytokines contained in the body can stimulate explants explants to form shoots. The addition of growth regulators type different from the same group as kinetin, zeatin and 2 iP into a medium that already contains Benzyl Adenine (BA) is sometimes needed to spur morphogenesis to be optimized.

\section{B. The number of shoots per explants}

The data were obtained using a $\log$ transformation has been in the $\mathrm{y}$ and the observations can be seen in Table 2 Table 2 shows that administration of BAP $3 \mathrm{mg} / 1$ with the addition of kinetin $0.5 \mathrm{mg} / 1$ was able to produce the highest number of shoots and the fruit 15.41 addition of kinetin with a higher concentration is $2 \mathrm{mg} / 1$ resulted in the lowest number of 4.66 shoots fruit. This is due to the provision of BAP $3 \mathrm{mg} / 1$ and the addition of kinetin $0.5 \mathrm{mg} / 1$ was the optimum concentration, because the content of cytokines in the explants are balanced so as to produce the highest number of shoots, but the addition of higher concentrations would be suppressing the growth of shoots. Wenas [25], PGR exogenous cytokinin especially needed in tissue culture media, especially species of woody plants, just need to set the balance of the growth regulator auxin especially. Because cytokinins are absolutely necessary for the growth of explants in culture, especially in the process of differentiation and proliferation.

TABLE III

THE NUMBER OF SHOOTS PER EXPLANT AGE 12 MST ON PROVIDING BAP 3 MG / L WITH SEVERAL CONCENTRATIONS OF KINETIN

\begin{tabular}{|l|c|c|}
\hline \multirow{2}{*}{ Treatment } & \multicolumn{2}{|c|}{$\begin{array}{c}\text { The number of shoots per explant } \\
\text { (apiece ) }\end{array}$} \\
\cline { 2 - 3 } & Data origin & Log transformation y \\
\hline BAP 3 mg/l + kinetin 0 mg/l & 9,79 & 0,98 a \\
\hline BAP 3 mg/l + kinetin 0,5 mg/l & 15,41 & 1,13 a \\
\hline BAP 3 mg/l + kinetin $1 \mathrm{mg} / 1$ & 10,50 & $1,02 \quad \mathrm{a}$ \\
\hline BAP 3 mg/l + kinetin $1,5 \mathrm{mg} / 1$ & 5,45 & $0,73 \quad \mathrm{~b}$ \\
\hline BAP 3 mg/l + kinetin 2 mg/l & 4,66 & $0,65 \quad \mathrm{~b}$ \\
\hline KK = 27,07 \% & & \\
\hline
\end{tabular}

The figures in the column followed by the same lowercase letter are not significantly different according to DNMRT 5\%

The number of shoots is an important factor in the multiplication of plants in tissue culture. Number of shoots in tissue culture may be indicated as success in multiplication. The more buds are formed, then the culture multiplication can be done to get new shoots in the growing number also. Kieber and Agustino [12] said cytokinin is involved in many aspects of plant growth and development, especially the formation of buds.

\section{Height shoots $(\mathrm{cm})$}

The observation of shoot height are presented in Table 3.

TABLE IIIII

HEIGHT BUDS APPEAR ON THE PROVISION OF BAP 3 MG / L WITH SEVERAL CONCENTRATIONS OF KINETIN.

\begin{tabular}{|l|l|}
\hline \multirow{2}{*}{ Treatment } & Average \\
\cline { 2 - 3 } & Shoot height $(\mathrm{cm})$ \\
\hline BAP 3 mg/l + kinetin 0 mg/l & $1,44 \quad$ c \\
\hline BAP 3 mg/l + kinetin 0,5 mg/l & $3,25 \quad$ a \\
\hline BAP 3 mg/l + kinetin $1 \mathrm{mg} / \mathrm{l}$ & $2,42 \quad$ b \\
\hline BAP 3 mg/l + kinetin $1,5 \mathrm{mg} / \mathrm{l}$ & $1,02 \quad \mathrm{c}$ \\
\hline BAP 3 mg/l + kinetin 2 mg/l & $0,93 \quad$ c \\
\hline KK = 27,07 \% & \\
\hline
\end{tabular}

The figures in the column followed by the same lowercase letter are not significantly different according to DNMRT 5\%

Based on Table 3 shows that each treatment significant effect in improving the high growth of shoots, the BAP treatment of $3 \mathrm{mg} / 1$ with the addition of kinetin $0.5 \mathrm{mg} / 1$ resulted in the highest shoot height of $3.25 \mathrm{~cm}$ and the 
addition of kinetin $2 \mathrm{mg} / 1$ resulted in high lowest shoots $0.93 \mathrm{~cm}$. This means that the treatment given at several concentrations capable of providing significant effect on shoot height produced, thus indicating the addition of a higher concentration of kinetin can inhibit the growth of shoot height and without the addition of kinetin at media treatment gives less stimulation of the growth of the cinchona plant shoot height in vitro. Giving BAP $3 \mathrm{mg} / 1$ with the addition of kinetin $0.5 \mathrm{mg} / 1$ showed that the treatment given in low concentrations can improve the high shoots optimum of all treatments given, in addition to the nutrients contained in the MS media to encourage the growth of shoots quinine. According Hoesen [11], the success of in vitro culture is determined by the growth regulator and basic media were used.

Giving BAP $3 \mathrm{mg} / 1$ with the addition of kinetin $0.5 \mathrm{mg} / \mathrm{l}$ is quite effective to spur the growth of shoots high, especially at low concentrations. However, the addition of a class of auxin IBA in the culture medium can increase the high growth of shoots [13]. According Wattimena et al [24], a growth regulator commonly used in combination, and morphogenesis of explants always depend on providing a balanced auxin and cytokinin. Gunawan [7] expressed the high response of tissue to grow due to the addition of auxin and cytokinin are able to change levels and cell growth regulator.

According Heddy [9], auxin can stimulate cell elongation, resulting in the elongation of coleoptile and stem. Unequal distribution of auxin is accompanied by swelling of the organ (geotropisme and phototropism). Stem elongation does not require high concentrations of cytokines or require exogenous cytokinin in low concentrations, because the content of endogenous cytokinin is sufficient. According Lakitan [14], the addition of exogenous cytokinin with high concentrations no longer be able to inhibit the growth effect even as the concentration of cytokines becomes excessive (supra-optimal).

\section{Number of Leaves (strands)}

The process begins with the development of shoots periklinal cell division in the lateral side (peripheral), area under the distal apical meristems. Periklinal cell division followed by cell growth that causes children to form primordial bulge leaves, whereas cell division antiklinal can increase the surface area of the leaf primordia. Primordial leaves supported by prokambium cells, further pro-cambium will be bone leaves [19].

The leaves are vegetative organs, growth is influenced by the nitrogen content in the media, but it leaves an important organ in plant growth, because the leaves as the site of photosynthesis is the process of formation of carbohydrates from $\mathrm{CO} 2$ and $\mathrm{H} 2 \mathrm{O}$ with the help of sunlight. The more the number of leaves, indicating that the better growth of explants.

The data were transformed using $\log y$, the observations can be seen in Table 4 .
TABLE IVV

THE NUMBER OF LEAVES FORMED AT 12 MST ON THE PROVISION OF BAP 3 MG / L WITH SEVERAL CONCENTRATIONS OF KINETIN

\begin{tabular}{|c|c|c|}
\hline \multirow[t]{2}{*}{ Treatment } & \multicolumn{2}{|c|}{$\begin{array}{l}\text { The number of shoots per explant } \\
\text { (apiece) }\end{array}$} \\
\hline & Data origin & Log transformation y \\
\hline BAP $3 \mathrm{mg} / 1+$ kinetin $0 \mathrm{mg} / \mathrm{l}$ & 39,75 & 1,59 \\
\hline BAP $3 \mathrm{mg} / 1+$ kinetin $0,5 \mathrm{mg} / 1$ & 61,75 & 1,73 a \\
\hline BAP $3 \mathrm{mg} / \mathrm{l}+$ kinetin $1 \mathrm{mg} / \mathrm{l}$ & 50,75 & $1,71 \quad \mathrm{a}$ \\
\hline BAP $3 \mathrm{mg} / 1+$ kinetin $1,5 \mathrm{mg} / 1$ & 29,21 & 1,43 \\
\hline BAP $3 \mathrm{mg} / \mathrm{l}+$ kinetin $2 \mathrm{mg} / \mathrm{l}$ & 26,00 & 1,42 \\
\hline $\mathrm{KK}=9,5 \%$ & & \\
\hline
\end{tabular}

The figures in the column followed by the same lowercase letter are not significantly different according to DNMRT 5\%

Table 4 shows that administration of BAP $3 \mathrm{mg} / 1$ with the addition of kinetin $0.5 \mathrm{mg} / 1$ and $1 \mathrm{mg} / 1$ resulted in the highest number of 61.75 and 50.75 leaves strands and the addition of kinetin with a higher concentration of $1.5 \mathrm{mg} / \mathrm{l}$ and $2 \mathrm{mg} / 1$ resulted in the lowest number of leaves 29.21 and 26 strands resulting in the formation suppression leaf number. Meanwhile, without the addition of kinetin to the medium treatment BAP $3 \mathrm{mg} / 1$ is not optimum growth because less stimulated to produce a number of leaves 39.75 . This is due to the formation of leaves on tissue culture propagation is also affected by the concentration of the hormone cytokine is added to the media. Along with the statement Purwanto [18], that the addition of group BAP cytokinin ratio higher than auxin in the media can encourage increasing the number of leaves.

\section{E. Shootlet Fresh weights ( $g$ )}

Observation data was performed using $\sqrt{y}+0.5$ transformation. The observation can be seen in Table 5 below.

TABLE V

WEIGHTS FRESH SHOOTLET AGE 12 MST ON PROVIDING BAP 3 MG / L WITH SEVERAL CONCENTRATIONS OF KINETIN

\begin{tabular}{|l|c|cc|}
\hline \multirow{2}{*}{ Treatment } & \multicolumn{3}{|c|}{ Shootlet Fresh weights (g) } \\
\cline { 2 - 4 } & $\begin{array}{c}\text { Data } \\
\text { origin }\end{array}$ & Transformation $\sqrt{\mathrm{y}}+0.5$ \\
\hline BAP 3 mg/l + kinetin 0 mg/l & 0,18 & $0,82 \quad \mathrm{~b}$ \\
\hline BAP 3 mg/l + kinetin 0,5 mg/l & 0,70 & $1,08 \quad \mathrm{a}$ \\
\hline BAP 3 mg/l + kinetin 1 mg/l & 0,37 & $0,93 \quad \mathrm{~b}$ \\
\hline BAP 3 mg/l + kinetin 1,5 mg/l & 0,14 & $0,80 \quad \mathrm{~b}$ \\
\hline BAP 3 mg/l + kinetin 2 mg/l & 0,13 & $0,79 \quad \mathrm{~b}$ \\
\hline KK = 9,5 \% & & & \\
\hline
\end{tabular}

The figures in the column followed by the same lowercase letter are not significantly different according to DNMRT 5\%

Shootlet highest fresh weight shown in Table 5, that the granting of BAP concentration of $3 \mathrm{mg} / 1$ with the addition of kinetin $0.5 \mathrm{mg} / 1$ resulted in fresh weight of $0.70 \mathrm{~g}$ and a top shootlet significantly different treatment accorded to all. With the addition of kinetin $2 \mathrm{mg} / 1$ resulted in fresh weight of $0.13 \mathrm{~g}$ shootlet low and not significantly different from the provision of BAP $3 \mathrm{mg} / 1$ with the addition of kinetin 0 , $0.5,1,1.5$ and $2 \mathrm{mg} / 1$. This may occur because the content of cytokinins has not been able to increase the weight shootlet formed, so that still require exogenous growth regulator auxin from class to improve wet weight shootlet. The resulting wet weight is dependent on the speed of these cells divide, multiply and continue with the growing shoots. Nevertheless, the provision of BAP $3 \mathrm{mg} / 1$ with the 
addition of kinetin $0.5 \mathrm{mg} / 1$ experienc-real influence on fresh weight shootlet, so with the addition of low concentrations could increase fresh weight shoolet.

Fresh weight shootlet large due the high water content. High water content is the result of at least the process of transpiration that occurs when cinchona plant shoots are in vitro conditions. According Dwidjoseputro [4] that $80 \%$ or more of the fresh weight of the plant life is composed of water. Besides, according Pierik (1987) nutrients essential for plant growth and development, without water and mineral nutrients plants can not survive in vitro and in vivo. It is also stated Prawiranata et al [17] reflect the fresh weight carbohydrate and nutrient composition of plant tissues by including the water content.

Towards the development of the culture is determined by the interaction and balance between growth regulating substances given in the media (exogenous) and produced by plant cells endogenously determine the direction of development of a culture.

Because within the explant itself existing endogenous growth regulator, but in the growth and development of man-tana-vitro growth regulator is added exogenously still need-even [23].

The addition of kinetin to the medium serves to encourage the process of morphogenesis shootlet, and may affect the stability of the number of plants in the plant cells in vitro quinine. According to Gunawan [7] Physiological role of cytokinins are downloading thrust cell division, morphogenesis of plant growth, bud formation and inhibits senescence and abscission.

\section{CONCLUSIONS}

Based on the experimental results obtained the best treatment for shoot multiplication of plants quinine (Cinchona ledgeriana Moens), namely the provision of BAP $3 \mathrm{mg} / 1$ with kinetin $0.5 \mathrm{mg} / 1$. This treatment gives the fastest response time of 5.92 HST shoots appear, the highest shoot height of $3.25 \mathrm{~cm}, 15.41$ highest number of fruit buds, forming strands of 61.75 the highest number of leaves, and the fresh weight of $0.70 \mathrm{~g}$ shootlet highest in plants quinine ledger age of 12 MST (Weeks After Planting).

Based on experimental conditions and the conclusion, to get the ledger can shoot multiplication quinine to culture the media with the best treatment, namely the provision of BAP $3 \mathrm{mg} / 1$ with kinetin $0.5 \mathrm{mg} / 1$. It is recommended to conduct further research for several concentrations of BAP and kinetin with the addition of auxin, thereby increasing shoot height and root formation, so that the formation of plantlets quinine ledger.

\section{REFERENCES}

[1] Arteca, R.N. 1996 Plant Growth Substances: Principles and Applications. Chaptman and hall. New York. 332 p.
[2] Dayrit FM, Guidotea A., Generalao ML, Serna C. 1994 Determination of the quinine content in the bark of the cinchona tree grown in the Mt Kitangland. Bukidnon. Phillip. J. Sci. 123 (3): 25227.

[3] Dodds, J.H. and L.W Roberts. 1995 Experiments in Plant Tissue Culture 3rd edition. Cambridge University Press. UK. 190 things.

[4] Dwidjoseputro, 1990 Introduction to Plant Physiology. New York: Scholastic. 177 things

[5] George, E. P. And P. D. Sherrington. 1984 Plant Propagation by Tissue Culture. Exegenics Limited, New York.

[6] Groothoff, A. 2006 Rational Exploitation of Plantation Kina. PPTK Bandung. 91 things

[7] Gunawan, W. L. 1988 Tissue Culture Technique. Plant Tissue Culture Laboratory. University Centre of the University. Bogor. 304 things.

[8] Hartman, H.T, D.E. Kester and F.T. Davies. 1990 Plant Propagation Princip and Practices. Fifth Edition. Prentice-Hall Intl., Inc. Philines. $521 \mathrm{p}$.

[9] Heddy, S. 1996 Plant Hormones. Jakarta: PT. King Grafindo Persada. 97 things

[10] Hendaryono, D.P.S and A. Wijayani. 1994 Tissue Culture Technique. Canisius: Yogyakarta

[11] Hoesen, 1998 DSH White Kunir Tissue Culture (Kaempferia rotunda L).

[12] Kieber, J. and I.B.D'Agostino. 2002 Molecular mechanisms of cytokinin action. Plant Biology, 1999, 2: 359-364. Department of Biological Sciences. Chicago

[13] Krikorian, A.D.M., Singh and C.E. Quina. Micropropagation of Cinchona Aceptic 1982: Prospects and problems in AN Rao (ed). Tissue Culture of Economically Important Plants. Proc.Int'l. Symp, Nation University of Singapore, 28-30 April 1981.

[14] Lakitan, B. 1996 Growth and Development of Plant Physiology. Jakarta: PT King Grafindo Persada. 218 things

[15] Lestari, e.g. Tissue Culture 2008. Akademia: Bogor 2012 in In Vitro Plant Regeneration and Influencing Factors. http://biogen.litbang.deptan.go.id (Accessed on 28 April 2014)

[16] Madjid, R. 1975 Kina Situation and Development in West Sumatra. news BPTK

[17] Prawiranata, W., H. Said and T. Pin. 1981 Basics of Plant Physiology. Department of Botany Faculty of Agriculture, Bogor, Bogor

[18] Purwanto, A. 2008 Study of Various Explants and concentration of IBA on Multiplication Mangosteen (Garcinia mangostana L) In In Vitro. [Thesis]. Faculty of Agriculture, University March Surakarta.

[19] Qosim, W.A., R. Poerwanto., G.A. Wattimena and Witjaksono. 2005 Establishment of Plantlets from Callus Mangosteen Nodular In Vitro. Zuriat, Vol. 16, No. 2 Bogor

[20] Riyadi, I. and J.S Tahardi. 2005 Effect of NAA and IBA on growth and development of shoots Quinine (Cinchona succirubra). Journal of Agricultural Biotechnology. Vol.10 No.2. pp 45-50

[21] Santoso, J., N.R. Mathius., U. Sastraprawira., G. Suryatmana., D. Sauda. 2004 Plant Propagation Quinine Cinchona ledgeriana Moens and C. Pavon succirubra Axillary Shoots Through Cloning. Tower Estate Journal 72 (1) 11-27.

[22] Santoso, TB 2013 Enhanced Production of Quinine Salts. PT. Plantation Nusantara VIII (Persero) .http: //www.pn8.co.id (Accessed on 30 April 2013).

[23] Santoso, U. and F. Nursandi. Plant Tissue Culture 2004. University of Malang Press. Malang

[24] Wattimena, GA Gunawan, LW, Mattjik, Samsudin, Wiendi, NA and Ernieati. Plant Biotechnology 1992. University Centre of Biotechnology, Bogor Agricultural University. Bogor

[25] Wenas, M. 2003 Effect of NAA and BAP Several Concentration on the Growth and Development of shoots shoots Gambir (Uncaria gambier Roxb) in In Vitro. [Thesis]. Padang. Faculty of Agriculture. University of Andalas

[26] Wibowo, Z.S., J. Santoso and Sukasmono. 1990 Effect of length and content of cuttings material Rootone-F on the Growth cuttings Quinine (Cinchona ledgeriana Moens) clones QRC. News Tea and Quinine. 1: 49-54 